\title{
Primary School Design: Co-Creation with Children
}

\begin{tabular}{|r|l|}
\hline Journal: & Archnet-IJAR: International Journal of Architectural Research \\
\hline Manuscript ID & ARCH-07-2020-0132.R1 \\
\hline Manuscript Type: & Research Paper \\
\hline Keywords: & $\begin{array}{l}\text { Primary School Design, School Garden, Co-design with Children, Co- } \\
\text { creation Methods, Participatory Design, Biophilic Design }\end{array}$ \\
\hline \multicolumn{2}{|l}{} \\
\hline
\end{tabular}




\section{Introduction}

Children are frequently disregarded in the society that most of the time adults make the majority of decisions for them. Co-designing with children challenges this point of view, opting to see children as social actors who are beings and not becomings (Clark, 2005). Research studies highlighted that children gravitate naturally to a purposeful engagement with their material world, and that they have strong feelings and lots of implicit knowledge about the environments they use every day (Hart, 1997; Chawla, 2001). Research into participatory practices, where school children and professionals work together on design and build projects (Sorrell, 2005; Ghaziani, 2012; Haffman, 2014) indicates that children are natural designers and experts in their own environments.

Therefore, as experts of their own experiences, it is important to include children in decisions regarding their everyday life, particularly design of their schools. This paper explores different data collection methods with children and presents the findings that emerged from children's perspective about the design of the educational spaces that they would like to have in their schools.

\section{Involving Children in Design}

An excessive deal of school architecture in England has been commissioned by clients who are not necessarily school users and direct communication between designers and users has regularly been limited to few school representatives (Parnell et al., 2008). Creating Excellent Primary Schools (CABE, 2010) highlights the importance of good design and includes a number of case studies and practical examples in the UK; however, children's involvement, specifically was not the focus of the case studies as the report does not present the details of methods and findings; however, it suggested to involve children and other school users in design process. There is a growing body of research and examples of involvement of children with architects (e.g. www.designingwithchildren.net, www.baupiloten.com) as well as UK's Government-led Building Schools for the Future Programme (BSF) of 20052010, which helped to mainstream school-based co-design projects between practitioners and stakeholders (Burke, 2007), including Joined up Design for Schools (Sorrell, 2005) and Young Design Programme (The Sorrell Foundation, 2006). As co-designers, the idea is to view children as equal stakeholders throughout the entire experience, contributing to the process as experts of their own lives. It is important to acknowledge their competence and provide them with methods of self-expression that encourages comfort and creativity.

User participation should be as part of the foundation for a design proposal, which leads to a design that is highly relevant in terms of use and increased sense of belonging (Hofmann, 2014). Co-designing with users indicates collective creativity applied across the span of a design process (Sanders and Stappers, 2008). In the recent years, designers have become increasingly aware of the value and expertise children bring to the design process by being included in many different ways. Druin (2002) describes four different roles a child can possess, namely that of a user, a tester, an informant or a design partner - these roles differ from merely observing to actively working with a child. As a user and a tester, the child is given a passive role to utilise and test 
new solutions while adults observe and learn from his or her experiences. However, as an informant, the child is expected to give input in various stages of the process, as a design partner he or she is considered an equal stakeholder throughout the entire experience.

Building further on Druin's model, a role was introduced that empowers the child more in a design process - seeing the child as the protagonist (Iversen et al., 2017). Treating the children as protagonists encourages reflection and for the them to be the main agents driving the entire process. The focus is not only on working together towards a product output, but to enhance the insight, design skills and the reflective thinking capabilities of the participants. Doorn (2016) expanded the role of the child in a design process even further, by introducing the role of co-researcher that enables the child to gather rich data because they share the same context as the participants in a design process.

When conducting a co-design project, good communication is vital and it needs a secure environment in which the children and the researcher/architect feel comfortable in order to be creative and discuss various ideas. In addition, as Hofmann (2014) recommends a trustful interaction between users (children) and architects that each respects the other's particular knowledge, expertise and respective roles is needed. Therefore, it is important to even the power gap between the researcher and the children and learn something valuable that children bring to the process. Finally, in order to extract children's views, codesign methods need to be adapted to the child's expressive needs. This study evaluates the different ways in which children could get involved in designing primary schools (indoor and outdoor spaces) to identify spatial design trends from the perspective of the children.

\section{Research Methods}

In order to obtain permission for this research, there were two stages to pass: 1) gaining authorisation from Faculty of Art, Design and Architecture at DeMontfort University, 2) obtaining permission from those under the schools' authority: headteachers, children and parents. Children between the ages of 8 and 10 in two Primary Schools in West Midlands, England, were participated. They were informed about different aspects of the co-creation project, and their own rights and privacy concerns. They were also informed that their opinions are of value for the school and the researcher.

The two schools with distinct architectural styles have been located in very different areas of the city. Earlsdon Primary School has been situated at the southwest of the city and is housed in a Victorian building which opened for in 1890. This is a school that is of high quality for high socioeconomic status students. In comparison, Broad Heath Primary School has been located in the north of the city in low quality socioeconomic status community. However, the school is a renovated modern building with state-of-the-art facilities and it had a massive extension in 2013 and was doubled in size.

Various data collection methods were used, including questionnaires, drawings and model making to gather children's views. Drawing allowed children to 
express their views about their environment (Sanoff et al., 2001) and as a visual strategy helped children to clarify a point under discussion (Cox and RobinsonPant, 2003); however, as drawings may be subject to false interpretations, it is essential to correlate these with a selection of other sources of information and to operate in an open exploratory way with children and their drawings (Greig and Taylor,1999). Therefore, to increase the validity of data, this study used a combination of data collection techniques to identify the meaning behind children's drawings and improve the quality of data analysis.

Following the Mosaic Approach, which includes three main stages (Clark and Moss, 2011), this study included another initial stage to inspire children with diverse design possibilities in order to encourage creative thinking as follows:

- Stage zero: presentation of various design examples to the children

- Stage one: gathering child's view by using individual questionnaire

- Stage two: piecing together the gathered views of children, allowing discussion of questionnaires in pairs and using drawing technique

- Stage three: presentation of suggested changes, using model making technique in groups.

\section{Studies and results}

\subsection{School garden design}

Majority of Primary School grounds are made of concrete and grass; however, they can be transformed into varied, ecologically-rich places of learning for children. This transformation can benefit from the co-design with children and the input of architects, landscape architects and educators. School ground greening is a term widely used for establishing gardens and varied plantings within schools (Dyment and Bell, 2007), and the rationales and benefits are countless and confirmed (e.g. Williams and Brown, 2012). Outdoor learning is believed to provide more memorable and stimulating learning experiences (Dillon et al., 2006; Nundy, 2001). The need for the outdoor learning has been emphasised by learning outside the classroom manifesto (DfES, 2006) as school gardens offer significant benefit in terms of learning through experience (McCarty et al., 2018) and increasing fruit and vegetable knowledge among children (Parmer et al., 2009).

Biophilic design patterns (Ryan et al., 2014) can be used in school grounds for greater connectivity between outdoor spaces and nature. A recent research on child-nature-distance studies that measures children's experiences of nature within three primary school spaces in Scotland, highlights well-designed educational environments are crucial to supporting the proximity to nature, particularly in the early years of schooling (To and Grierson, 2019). In addition, there has been growing movement of outdoor learning in recent government investments, including Nature Friendly Schools (The Wildlife Trusts, 2019) to support schools in increasing children's opportunities to learn outside the classroom. However, a recent study of school grounds and their use to support biodiversity conservation and children's environmental education revealed that 
British schools are under-using their grounds to provide habitats and environmental education (Harvey et al., 2020). Therefore, planning and designing child-centred outdoor spaces in schools is crucial nowadays.

Earlsdon Primary School decided to extend its school ground greening by buying the triangle shaped land behind the school playground and convert it to a garden for children. Therefore, it was a great opportunity for children to be involved in design process. In June 2019, 30 Year 4 children in Earlsdon Primary School participated to design a garden for their school behind the existing playground area. Their teacher, teaching assistant and the researcher were assisting children at different stages of this co-creation project - design of a peace garden influenced by Japanese gardens - during the school day.

The project started with presentation of few slides related to basic rules in the design of Japanese gardens, examples of garden design (images and drawings) and basic information about the site and scale. After the presentation in Year 4 classroom and explaining different stages for the project, children completed their individual questionnaires. Next stage was drawing in pairs. Children were given a site drawing of $1 / 50$ scale on A3 size paper to draw their suggested design related to their questionnaires as discussed in pairs (see Figure 1).

[Figure 1]

Final Stage was model making (in groups of three children). Each group was given a site drawing of $1 / 50$ scale on a cardboard to start their model making. Moreover, they were given few model making figures (of people) to help understand the scale of their models. Children could use the school hall beside their classroom as more space was needed for this part of project. They could access different materials that were provided for them by the researcher and the school. The researcher, teacher and teaching assistant were assisting children to access the materials that they needed for their models. Figure 2 presents the process of model-making by children and their final models. 
[Figure 2]

The most preferred space in the garden was relaxing area by water (waterfall, pond, foundation) as part of the design. Besides, reading corner and sports area were equally chosen as the second preferred spaces. In addition, the main materials suggested to be used in the garden were 'wood' and 'stone; however, 'bamboo' and 'sand' were chosen by some children.

Regarding the features, most children suggested they would like to have 'flower garden' (83\%) with the paths (93\%) and 'benches/seating' (93\%). 'Grasse' was suggested by $73 \%$, while 'evergreen plants' were chosen by $63 \%$ and 'four season interest' by $50 \%$. Interestingly, sculpture was identified as preferable feature by $73 \%$ and 'water features' (including ponds, waterfall and water fountain) were suggested by $60 \%$ of children. Finally, a bridge over the pond was preferred by $53 \%$ and stepping stones were suggested by $50 \%$ of children.

Majority of children suggested their designed garden responds to different senses by including the following features in order as follows.

- Sound:1) running water (the most preferred feature) 2) birds 3) waterfall

- Touch:1) stones 2) flowers 3) trees 4) rocks 5) bamboo

- Sight:1) animals (e.g. birds, Kio fish, squirrel) 2) water and waterfall 3) flowers, plants 4) bridge 5) trees

- Smell:1) flowers (e.g. Lavender) 2) nature (e.g. moss, herbs, plants)

Overall, regarding their feelings, children expressed this suggested garden makes them happier (93\%) and it can help them feel relax (93\%). Finally, children completed a short evaluation form and highlighted that all enjoyed the design and model making experience.

\subsection{Re-design of indoor spaces}

This study was conducted at Broad Heath Primary School in June 2019 to involve children in re-design of two spaces - the Studio (Figure 3a) and School Hall (Figure 3b). The project started with presentation of various examples of school halls, dining halls and multi-function spaces in different schools. The 
Power Point presentation for 90 children in Year 5 (in three classrooms) was carried out in the Studio - one of the spaces that children planned to re-design.

[Figure 3 here]

The children came back to their classroom and started completing their individual questionnaires; however, children in two classrooms focused on redesign of the Studio and children in the third classroom carried out with redesign of their school hall. All children started to draw their ideas as sketches before starting model-making in groups of three or four. Children could use the corridor beside their classroom to access different materials that were provided for them by the researcher. The children who completed their models were asked to write a summary of their idea on a piece of paper. Although not all children could re-design both spaces in the allocated time, a number of them were able to.

\subsubsection{Re-design of Studio}

54 children in Year 5 participated to re-design the studio - a multi-functional space that can be used for drama, PE, assemblies and lunchtime clubs. Children were asked what they do not like about their studio and they stated the studio is too hot, looks dull and the floor is hard. Regarding the change, children suggested that they would like to change the walls (by adding colours and patterns, removing the characters, adding plants, windows and hexagonal shape seats nested in the wall), the ceiling (including fans and air conditioning, adding colours and making the sky show), the floor (by adding carpet and beanbags, having extra floor accessible by a staircase). Figure 4 presents few suggested ideas. Moreover, regarding the colours, children suggested they would like varied bright colours - 'blue' was chosen by over $50 \%$, while 'red and green' were equally selected by almost $30 \%$ of the children. For artwork, children suggested abstract, 3D artwork as well as patterns of nature (including trees and waterfall). 
In addition, children shared their views related to various surfaces. For redesign of walls, children advised painting them to 'change their colours'. They also suggested inclusion of the walls that can store 'seats' in them as well as living planted walls. Children highlighted that they would like to add colours to the floor and change the material in order to be soft and comfortable (e.g. carpet). Regarding the ceiling, they suggested adding colours and the use of glass (window) to make the sky show.

[Figure 4 here]

For lighting design, children suggested different colour lighting with different shapes, (including star, leaf, and flower shapes) as well as various types, such as spot lights and hanging lights. Finally, for furniture type, the suggestions were 'big bean bags', 'cushions', 'soft chairs', 'sofas', and 'hexagonal seats' that can be set on the walls.

[Figure 5 here]

Children could present their ideas for change through modelmaking in groups successfully. Although it was not possible for researcher to talk with all the 
groups because of time limitation, they shared the summary of their ideas in a written format on a piece of paper as follows.

- We were going to make a 3 layered re-design of the studio. The first of which would be a forest wall and red floor with board games. The other 2 floors would also be board games. But in the end, we only managed to make [one floor with] the forest wall" (Figure 5a).

- "We made one design. Design was based on the outdoors. Inside our model we have clouds, cloud lights and fake grass with a blue sky. We also have a pond ring and some plants pots" (Figure 5c).

- "The colours we used were red, orange, hot pink, yellow, for the sunset and dark purple with light blue for the ocean. We also made a floor type of thing out of the wood. We cut some short and left some long" (Figure 5d).

- "There will be two parts. The first part has a projector so you can watch things. There are seats and plants there. The second part has TVs for learning and we will grow plants in there. There will be a bug open space with a window. There is a mirror, which will reflect light from the window and that will make plants grow."

- "We created a nature studio... we used our imagination to make vines, roses and trees to give it the nature touch. We put 4 LG TV's in for learning...couches with cushions, were also put in...it turned out really nice and enjoyable. This is a great opportunity for other children to explore and have fun in our beautiful nature studio."

\subsubsection{Re-design of School Hall}

This study was conducted with 45 Year 5 children as participants. Children mentioned that they like their school hall because the activities they do (including P.E and dining) as well as being spacious and having a skyline wall; however, they expressed their dislike for the hall being dull and plain. Children suggested that they would like to change the ceiling to be opened and closed to let light and air in. They also proposed the change for the walls and floor by adding more colours and patterns. Regarding the preferred colours, almost half of the children chose 'blue' and $40 \%$ selected 'red' and almost $30 \%$ preferred 'green'.

For changing the windows, they suggested making them bigger and colourful. Children asked for more 'natural light' and re-design of artificial lighting (e.g. LED, hanging lights, and colourful lights). For re-designing the walls, children suggested making them colourful- similar suggestion for re-design of the floor. Regarding the ceiling, they asked for a transparent ceiling that can be opened and closed. 
[Figure 6 here]

Children also presented their ideas by making physical models in groups and writing notes to explain their models (see Figure 6). Some of their notes are as follows.

- "The model that we were making included cutting out shapes for the floor and making stairs out of clay. We were making a two-story hall with hexagons on the walls so we can [sit to] read or relax."

- "Our model is a stage which comes out from the wall and has mini seats. There is an on and off button. There is also a galaxy wall."

- "Our ideas are a platform for resting, more natural light, [and] abstract art on the walls."

\section{Discussion}

\subsection{Methods for co-creation with children}

Innovative architects declared that they cannot create a school for the future by themselves; therefore, they consider participations of the school users as central to the architect's agenda and talk about the child as the 'addressee' about instruction as the 'soul' of the building and the joy of learning, and the eagerness to achieve (Walden, 2009). Using methods and materials that match the child's set of skills seems crucial to optimise the outcome of a co-creation session with children. The co-design process for the studies was educational and fun for children, contained activities that encouraged the children to feel ownership of the project from the very beginning.

As Doorn (2016) highlighted it is beneficial to set up a learning environment in which the children can learn from and give constructive feedback to each other. In these studies, working in pairs and groups provided this opportunity for children to share ideas and learn from each other. A review of the various methods shows that there are two main classifications used in research involving children: 'evaluative' methods and 'creative' methods (Ghaziani, 2009). There are a number of evaluative methods which may be applied. Photo questionnaires and interviews are effective means for eliciting evaluative comments about physical settings (Sanoff et al., 2001). 
When children do 'create' visual data, the methods for free expression include drawing and model making. 'The school l'd like' 2001 competition also used model marking and drawings as methods to gather children's views in 150 primary and secondary schools (Burke and Grosvenor, 2003). Model making workshops with children were also used for the project named 'Joined up design for schools' with involvement of around 100 schools and 700 pupils in client teams (Sorrell, 2005). Model making has benefits because, unlike drawing, the materials can be easily moved around until the child is happy with their decision of where to place something. Drawings however require a commitment that is not so easy or flexible to erase (Hart, 1979;1997). Physical modelling with a variety of materials is an effective method to explore the learning environment through children's perceptions and to understand what children find important in their surroundings. This method is fun and allows children to really enjoy putting their perspectives across; however, it takes time (often several hours) and children should be allowed to complete their work (Johnson et al., 2014). However, using several data collection methods beside model making is challenging in a school day because of time limitation and working with many children; therefore, it is hard for children to create complete models with all the details as these studies revealed.

To increase the validity of data, researchers use a combination of methods of data collection (Lewis and Lindsay, 1999). Alison Clark's Mosaic Approach suggests a meaningful exchange of opinions between children and adults in a participatory design process (Clark, 2005). It includes various activities and methods to accompany children's numerous ways of expressing themselves, which has been inspired by Reggio Emilia's hundred languages of children theory (Hewett, 2001). Therefore, for these studies incorporating various methods (questionnaires, drawings and model marking) for children to allow self-expression helped the researcher to understand the story behind children's drawings and improve the quality of data analysis. However, children's discussion during completing the questionnaires and sharing their responses (as children have been close to each other around the tables in the classrooms) might be a disadvantage of questionnaires. Drawings with some notes have been an effective method for children to express their views (individually and in pairs) as well as model making in groups (with notes to explain the drawings). In addition, it was observed that despite the use of different methods, children's responses were convergent. Overall, the studies revealed these three methods could engage with skills and abilities of children; however, more research is needed to gather children's views about these data collection methods.

It needs to be mentioned that for creating visual data and suggesting changes, the presentation (stage zero) was significantly important as the analysis of children's drawings, models and questionnaires demonstrated inspired new ideas and raised issues related to the examples (images) presented to them; therefore, it might be a vital stage to be included in gathering views of children, especially at primary schools, in order to nurture and inspire children's innovation and creativity; however, it was identified that the researcher's agendas to some extent shaped the responses of children. In addition, the power gap between children and the researcher was bridged by informing 
children about professional conventions of model-making and drawings and assisting them to express their views.

Finally, the studies revealed that flexibility (for time and task plan) to work with a large number of children is needed as children have got different interest and pace in various methods to be involved (resulted in a smaller number of questionnaires, drawings and model making for the second study). Although these data collection techniques worked well for these studies before the pandemic, other methods (possibly online) may need to be explored for postCOVID time as access to the schools and contact with children in the schools would be more challenging for the researchers.

\subsection{Children's views}

In designing schools, it is important to recognise that a new building is not the finished product and even in the short-term good school buildings need to allow children to take ownership, experiment and change how they use the space (Mirshandani and Wright, 2016). Considering the previous studies, there have been similarities between the findings of this study and the issues emerged from analysis of previous studies (The School l'd Like, Joinedupdesignforschools, The Young Design Programme) in the UK (Ghaziani, 2008).

Although there have been concerns for contemporary school gardens because of modern childhoods that children being disconnected from nature (Williams and Brown, 2012), children presented their interest to be connected to nature and natural features (biophilic design). The findings had similarities to what 'the school l'd like' 2001 competition emphasised about children's ideas for their school yards - lots of spaces to be filled with ponds and gardens. With younger children, there was a further theme expressed, which was the need for more natural features, including water, wildlife and animals (Burke and Grosvenor, 2003). Similarly, analysis of previous studies presents children's interest to access to the landscape (e.g. trees, garden, mazes, grass, wild garden, ponds) and inclusion of seats, a pet corner or bird boxes in the school ground (Ghaziani, 2008) as also highlighted by children in this study. Although this study provides additional details related to the garden design in primary schools, it could be considered as a pilot study because of the limited number of children participated.

The importance of garden design in primary schools and the effective connection to nature for children's mental health is even more important for post Covid school design. School ground could be more important than before, not just for outdoor learning, but also for break time. The evidence shows that being outside reduces transmittance of the virus; therefore, schools can take advantage of this and exploit the opportunities for outside space. It also has been highlighted as one of the design considerations for school design to include more outdoor learning through external classrooms - greater consideration of the principles of forest schools, particularly for younger children (Waite, 2020). The 'protective measures' outlined in the guidance say schools 
should be looking to teach children outside more often as Tom Waddicor, an associate at Maccreanor Lavington Architects believes exterior space will become 'ever more valuable in schools' and would be an opportunity 'for a new wave of innovative outdoor classrooms' (Waite and Ing, 2020).

Regarding the interiors, the emerged similar issues were 1) the interior is softly textured (e.g. carpet), 2) the walls and floors are colourful, 3 ) the interior provides means to display art work, 4) there is some decoration in the dining spaces. The emerged similar items related to comfort and control based on previous studies include 1) satisfactory levels of natural light (windows, sky/ roof light), 2) appropriate types of artificial lights (e.g. spot lights), 3) natural ventilation, and 4) provision for air-conditioning. Moreover, connection to nature (biophilic design patterns) was important in interior spaces for children in this study, which has been emerged in previous studies - a view to nature when you are inside the building (e.g. plants, trees). In addition, related to furniture, similar emerged issues from previous studies (Ghaziani, 2008) support the findings of the second study - providing appropriate chairs (soft cushioned).

Despite the similar finding, the previous studies have not been specific about multi-functional spaces in schools. Therefore, the study of two interior spaces provides insight into multi-functional spaces in primary schools for designers and architects to include children's views in design process (for renovation and future school design); however, post-COVID school design needed additional considerations as not all children would be together at the same time for assembly, dining and other activities. In addition, almost every space in future schools should be considered as a multi-function space in order to keep children together in 'bubbles' (with their teacher) throughout the day and minimise contact and mixing; Therefore, flexible and adaptable design of large shared spaces in the primary schools, including school halls and dining spaces would be essential. In addition, selecting appropriate materials for various surfaces and furniture that are easier to clean and do not support bacteria and viruses is essential. Finally, more research focusing on diverse spaces, various age groups and in different primary schools would provide reliable and ageappropriate guideline for future school design.

\section{Conclusion}

As education system is changing (especially after this pandamic), future schools need to deliver flexible and adaptable buildings; therefore, an engagement process that allows for vigorous dialogue between designers, building users (including children) and educationalist is needed (Mirshandani and Wright, 2016). On the other hand, educationalists and children should be completely involved in the design process, actively participating both in the creation (or transformation) and the maintenance of their learning environment. Architects, landscape architects and support professionals must become hands-on facilitators and leaders of thoughtful and relevant change - or must work with those who are and can (DfES, 2006). 
As Walden (2009) suggests, schools of the future should take the experiences of children into consideration as their buildings and outdoor spaces are planned; however, review of literature suggests that the majority of studies have been focused largely on school buildings because architects or landscape architects are not often involved in helping schools develop school grounds into places of biodiversity and experiential learning, and this is mainly undertaken by schools themselves. In addition, there is usually lack of money in schools for nonessential spaces, such as school gardens.

Spatial production is a collective forming process which empowers architects and users alike as Petrescu (2012) highlights. Listening to children's opinions and their creative input is beneficial for the school design process and will help create stronger and more effective outcomes. Children are capable of articulating their views about their school environment in different ways. As emerged from the studies, use of various data collection methods, including questionnaires, drawings and model marking work effectively with Y4 and Y5 children (8 to 10 years old). Although co-design with children encourages and challenges researchers, designers and children to work together outside of their own comfort zones, it enables them to acquire new knowledge based on a mutual learning experience, which forms the basis for idea generation.

Allowing children to express their views about different spaces in their schools through methods that are familiar to them will enable designers and researchers to design better schools in future for children as the ultimate clients. However, more research is needed to explore various methods of data collection with children to gather their views about these methods. The findings suggest that some consistency in children's views was apparent; however, more data analysis should be undertaken with a larger number of children to explore their views further in order to make a framework for school design. Such research could bridge the gap between designers' assumptions and children's views about what is important in a school and consequently play a significant role in improving school design and increasing child satisfaction. In the future, it would be interesting to explore how the child's role as a main driver of the design process could be developed further, and more age-appropriate research methods (for evaluation and creation) with children in different years and appropriate for post-COVID can be used in primary schools.

Finally, the findings highlight the importance of involving children in the school design process that could then inform the decision-making processes of architects, designers and educators to look at problems from a child's standpoint. It is also important to gather views of teachers and involve them in the design process. The study demonstrate how research can be embedded in primary/elementary schools for improving the existing learning environment (buildings and grounds), possible renovations and extensions in schools and incorporating biophilic design. It is recommended to gather children's and teachers' views related to the changes that primary schools in the UK have applied in response to the pandemic since June 2020 to assess the impact of social distancing in various indoor and outdoor spaces. It is also recommended that designers examine the inclusion of flexible and adaptable schools for children and teachers with consideration of their needs, preferences, health and 
well-being. Therefore, more research needs to be carried out to find out how outdoor spaces can be improved and if almost every indoor space should become a multi-function space; and what this would mean for large shared spaces, such as school hall and dining spaces and whether they could be used for small spaces for learning.

\section{References}

Burke, C., 2007. The view of the child: Releasing 'visual voices' in the design of learning environments. Discourse: Studies in The Cultural Politics of Education, 28(3), pp. 359 - 372.

Burke, C. \& Grosvenor, I., 2003. The School I'd Like - Children and Young People's Reflections on an Education for the 21st Century. London: Routledge Falmer.

CABE, 2010. Creating excellect primary school: A guide for clients. [Online] Available at: https://www.designcouncil.org.uk/sites/default/files/asset/document/creatin g-excellent-primary-schools 2.pdf [Accessed 10 April 2020].

Chawla, L., 2001. Growing Up in an Urbanising World. London: Earthscan Publications/UNESCO Publications.

Clark, A., 2005. Ways of seeing: using the Mosaic approach to listen to young children's perspectives. Bristol: Policy Press.

Clark, A. \& Moss, P., 2011. Listening to Young Children: The Mosaic Approach. 2nd ed. London: National Children's Bureau.

Cox , S., Robinson-Pant, A., Elliot, B., Jarvis, D., Lawes, S., Millner, E., Taylor, T., 2003. Empowering Children through Visual Communication. Norwich: University of East Anglia .

DfES, 2006. Learning Outside the Classroom, Nottingham: DfES Publications.

DfES, 2006. Schools for the Future: Designing School Grounds. [Online] Available at:

https://assets.publishing.service.gov.uk/government/uploads/system/uploa ds/attachment data/file/276691/schools for the future -

designing school_grounds.pdf

[Accessed 15 April 2020].

Dillon, J., Rickinson, M., Teamey, K., Morris, M., Choi, M.Y., Sanders, D., Benefield, P., 2006. The value of outdoor learning. The School science review, Volume 87, pp. 107-111. 
Doorn, F., 2016. Children as co-researchers in design: Enabling users to gather, share and enrich contextual data. PhD. Delft University of Technology. [Online]

Available at:

http://pure.tudelft.nl/ws/portalfiles/portal/4732335/PhD thesis Fenne van Doorn Children as co researchers in design.pdf [Accessed 10 May 2020].

Druin, A., 2002. The role of children in the design of new technology. Behaviour and Information Technology, 21(1), pp. 1-25.

Dyment, J. \& Bell, A., 2007. Active by Design: Promoting Physical Activity through School Ground Greening. Children's Geographies, 5(4), pp. 463477.

Ghaziani, R., 2008. Children's voices: raised issues for school desig. CoDesign, 4(4), pp. 225-236.

Ghaziani, R., 2012. Design Frameworks for Schools: Facilitating the Involvement of School Users in the Design Process. Saarbrücken: LAP LAMBERT Academic Publishing.

Greig, A., Taylor, J. \& Mackay, T., 1999. Doing research with children. 1st ed. London: SAGE.

Hart, R., 1979. Children's Experience of Place: A Developmental Study. New York: John Wiley \& Sons Inc.

Hart, R., 1997. Children's Participation: The Theory and Practice of Involving Young Citizens in Community Development and Environmental Care. London: UNICEF/Earthscan.

Harvey, D., Gange, A. \& Harvey, H., 2020. The unrealised potential of school grounds in Britain to monitor and improve biodiversity. The Journal of Environmental Education, [e-journal] 51(4), pp. 306-316.

https://doi.org/10.1080/00958964.2019.169330

Hewett, V., 2001. Examining the Reggio Emilia Approach to Early Childhood Education. Early Childhood Education Journal, 29(2), pp. 95100.

Hofmann, S., 2014. Architecture is Participation: Die Baupiloten - Methods and Projects. Berlin: JOVIS Verlag.

Iversen, O., Smith, R. \& Dindler, C., 2017. Child as Protagonist:

Expanding the Role of Children in Participatory Design. IDC 2017:

Proceedings of the 2017 Conference on Interaction Design and Children, [e-journal] pp. 27-37. https://doi.org/10.1145/3078072.3079725

Johnson, V., Hart, R. \& Colwell, J., 2014. Steps for Engaging Young Children in Research - Volume 2: The Researcher Toolkit. [Online] 
Available at: https://bernardvanleer.org/publications-reports/stepsengaging-young-children-research-volume-2-researcher-toolkit/ [Accessed 15 April 2020].

Lewis, A. \& Lindsay, G., 1999. Researching Children's Perspectives. Buckingham: Open University Press .

McCarty, J., Ford, V. \& Ludes, J., 2018. Growing Experiential Learning for the Future: REAL School Gardens. Childhood Education, [e-journal] 94(2), pp. 47-55.

https://doi.org/10.1080/00094056.2018.1451690

Mirchandani, N. \& Wright, S., 2016. Future Schools: Innovative Design for Existing and New Buildings. Newcastle upon Tyne: RIBA Publishing.

Nundy, S., 2001. Raising achievement through the environment: The case for fieldwork and field centres. Walsall: National Assocication of Field Studies Officers (NAFSO).

Parmer, S., Salisbury-Glennon, J., Shannon, D. \& Struempler, B., 2009. School Gardens: An Experiential Learning Approach for a Nutrition Education Program to Increase Fruit and Vegetable Knowledge, Preference, and Consumption among Second-grade Students. Journal of Nutrition Education and Behavior, [e-journal] 41(3), pp. 212-217. https://doi.org/10.1016/j.jneb.2008.06.002

Parnell, R., Cave, V. \& Torrington, J., 2008. School design: Opportunities through collaboration. CoDesign, 4(4), pp. 211-224.

Petrescu, D., 2012. Relationscapes: Mapping agencies of relational practice in architecture. City Culture and Society, 3(2), pp. 135-400.

Ryan, C., Browning, W., Clancy, J., Andrews, S., Kallianpurkar, N., 2014. Biophilic design patterns: Emerging nature-based parameters for health and well-being in the built environment. International Journal of Architectural Research, 8(2), pp. 62-76.

Sanders, E. \& Stappers, P., 2008. Co-creation and the new landscapes of design. CoDesign, 4(1), pp. 5-18.

Sanoff, H., Pasalar, C. \& Hashas, M., 2001. School Building Assessment Methods. [Online]

Available at: https://files.eric.ed.gov/fulltext/ED448588.pdf [Accessed 18 March 2020].

Sorrell, J. \& Sorrell, F., 2005. Joined Up Design for Schools. 1st ed. London: Merrell Publishers Ltd.

The Sorrell Foundation, 2006. Young Design Programme. [Online] Available at: https://www.thesorrellfoundation.com/wpcontent/uploads/2017/06/Young-Design-Programme-Magazine-2005- 
06.pdf

[Accessed 10 May 2020].

The Wildlife Trusts, 2019. New 'Nature Friendly Schools' to help 'green' hundreds of school grounds and bring thousands of children closer to nature. [Online]

Available at: https://www.wildlifetrusts.org/news/new-nature-friendlyschools

[Accessed 18 October 2020].

To, P.T. \& Grierson, D., 2019. An application of measuring visual and nonvisual sensorial experiences of nature for children within primary school spaces: Child-nature-distance case studies in Glasgow, Scotland. Archnet-IJAR, [e-journal] 14(2), pp. 167-186. https://doi.org/10.1145/3078072.3079725

Waite, R., 2020. Coronavirus: Can primary schools adapt to a postlockdown world?. [Online]

Available at: https://www.architectsjournal.co.uk/news/coronavirus-canprimary-schools-adapt-to-a-post-lockdown-world [Accessed 25 May 2020].

Waite, R. \& Ing, W., 2020. Coronavirus crisis: What now for schools and offices?. [Online]

Available at: https://www.architectsjournal.co.uk/news/coronavirus-crisiswhat-now-for-schools-and-offices

[Accessed 30 May 2020].

Walden, R., 2009. Schools for the Future: Design Proposals from Architectural Psychology. Göttingen: Hogrefe \& Huber Publishers..

Williams, D. \& Brown, J., 2012. Learning Gardens and Sustainability Education: Bringing Life to Schools and Schools to LifeLearning Gardens and Sustainability Education: Bringing Life to Schools and Schools to Life. New York: Routledge. 


\section{Figures}

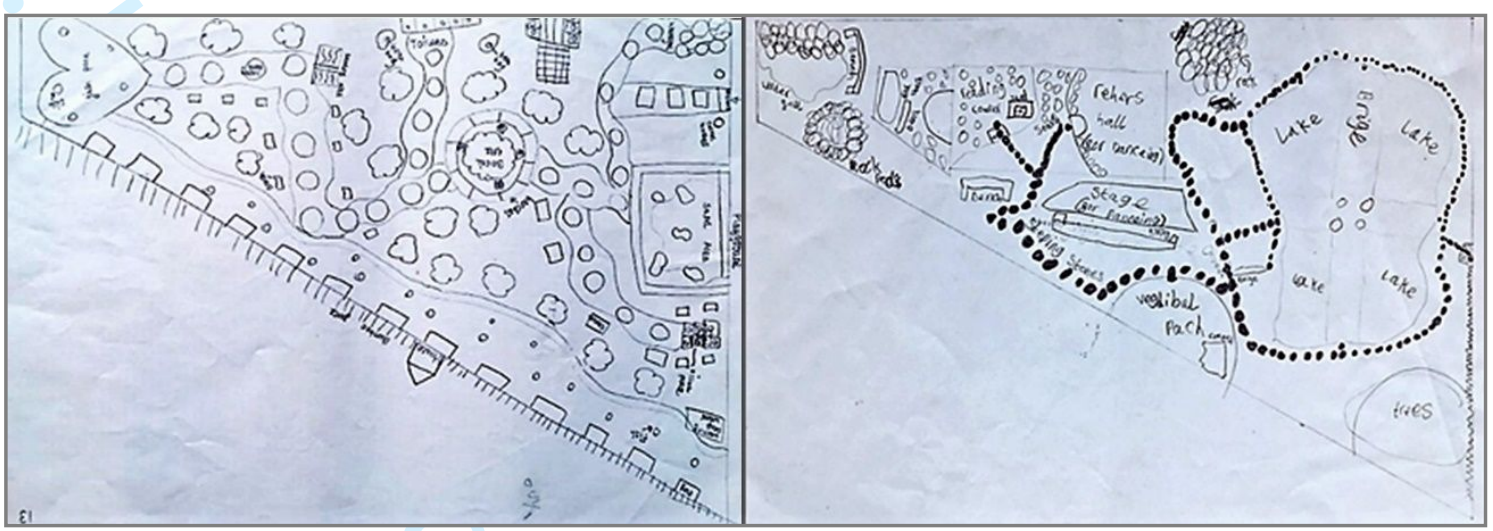

Figure 1

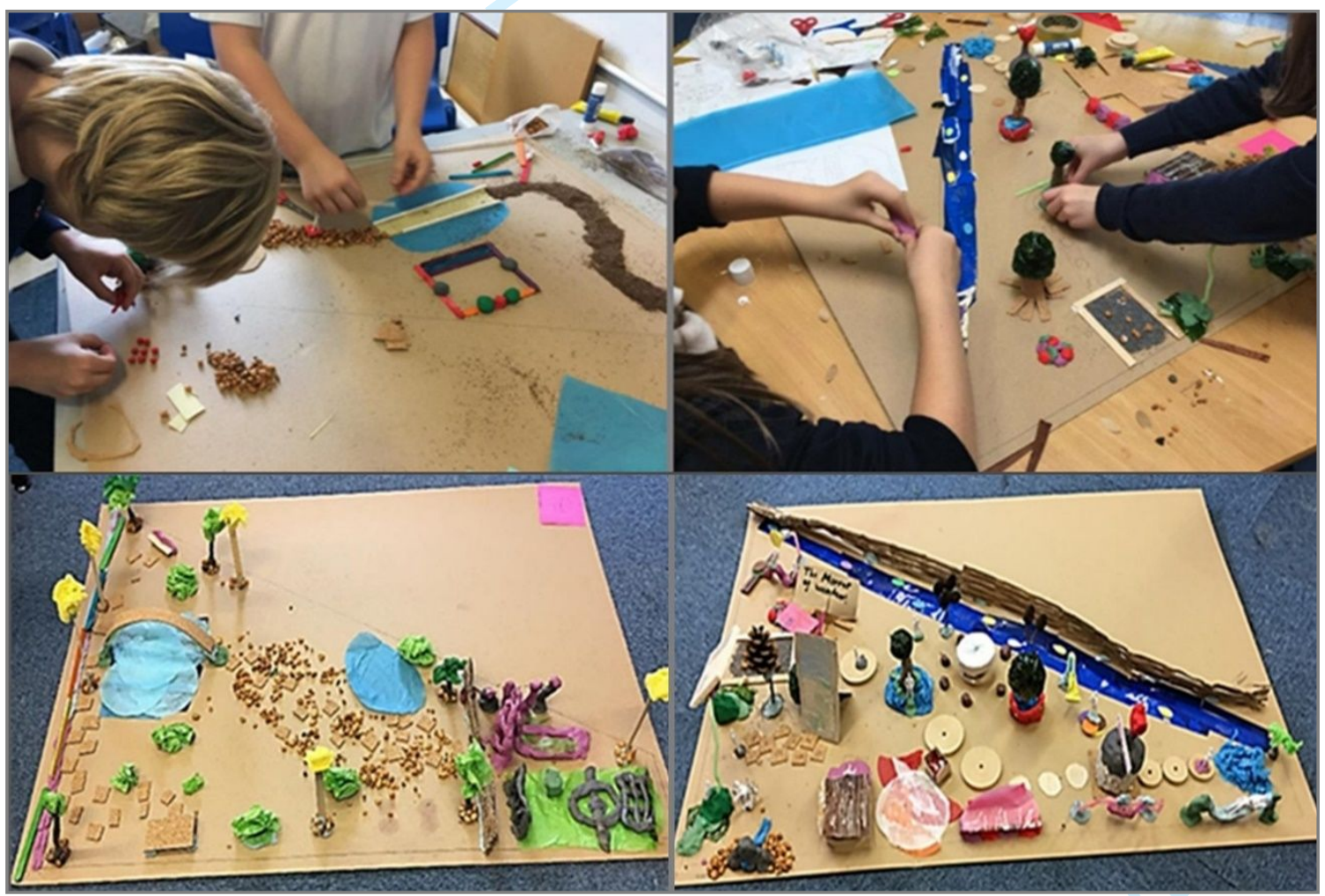

Figure 2 


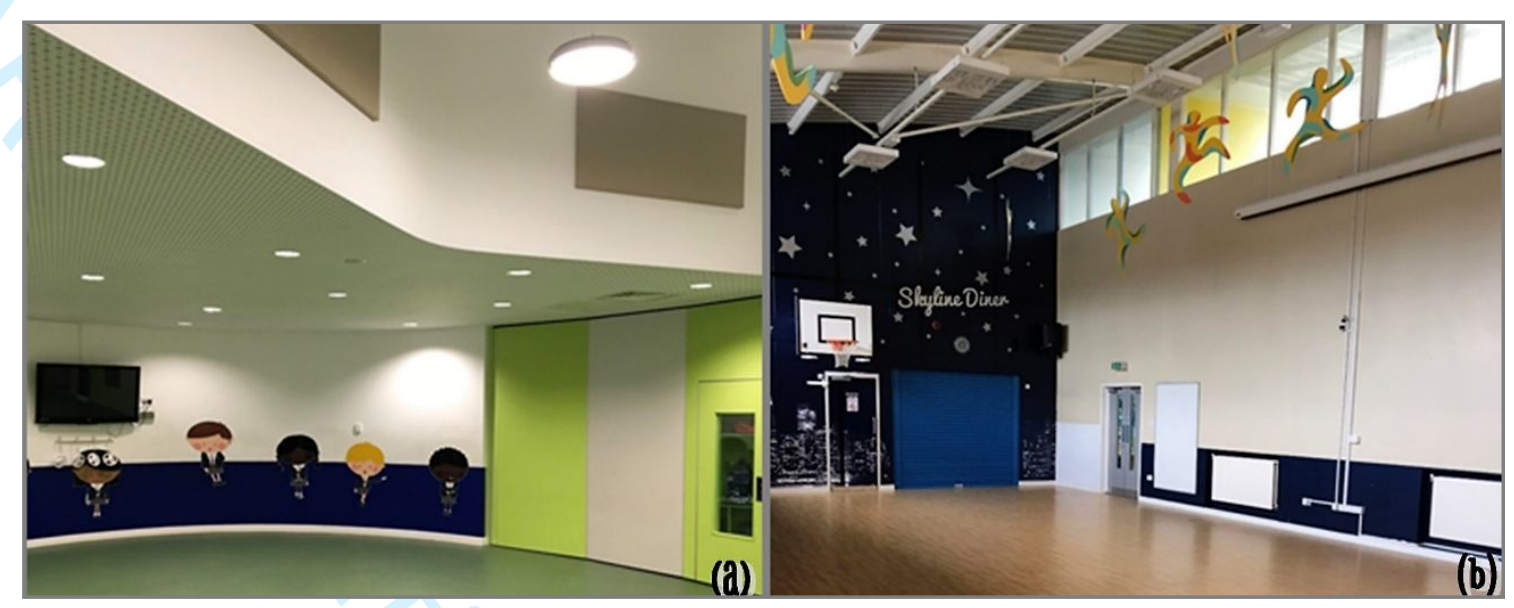

Figure 3 


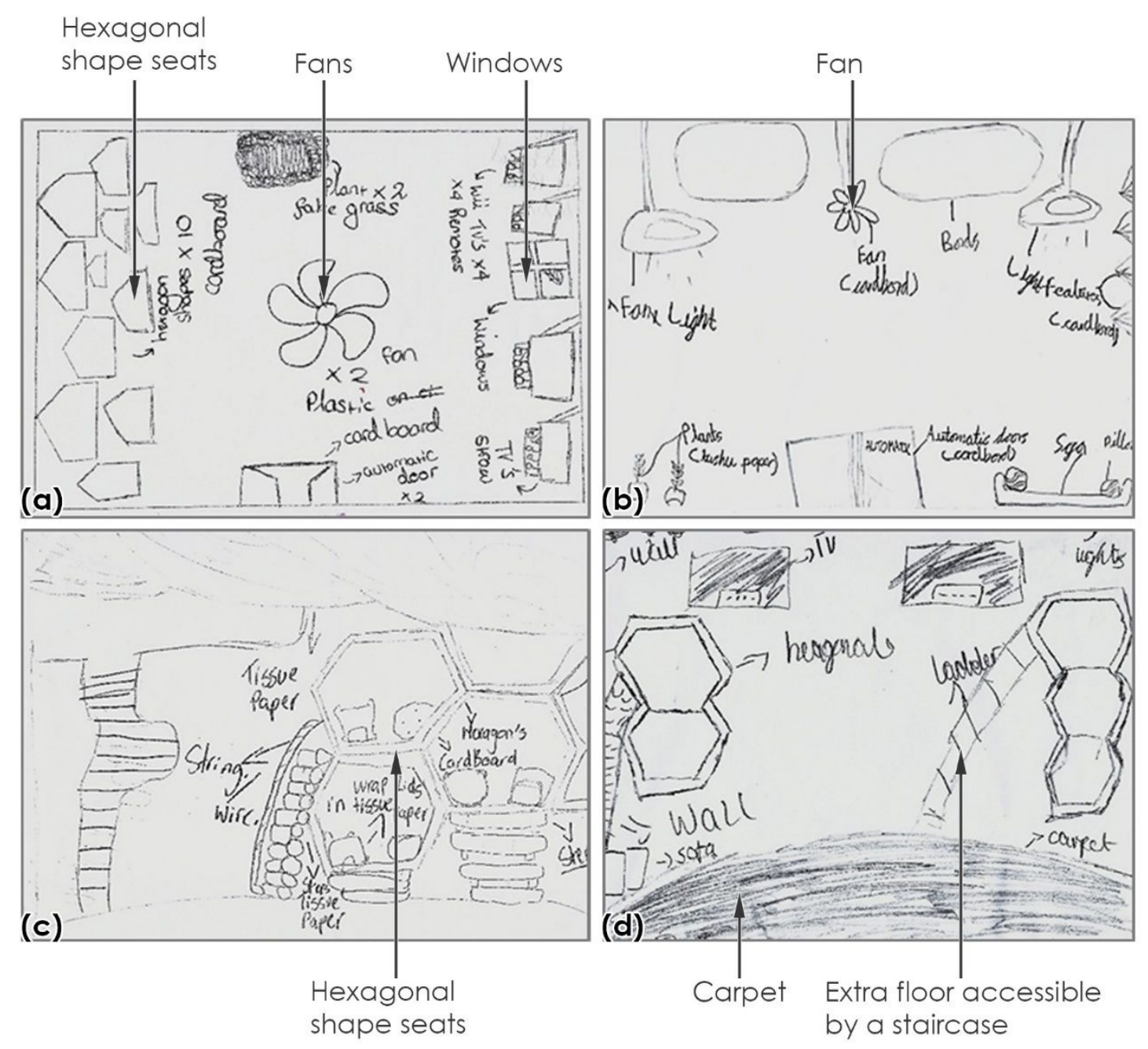

Figure 4 


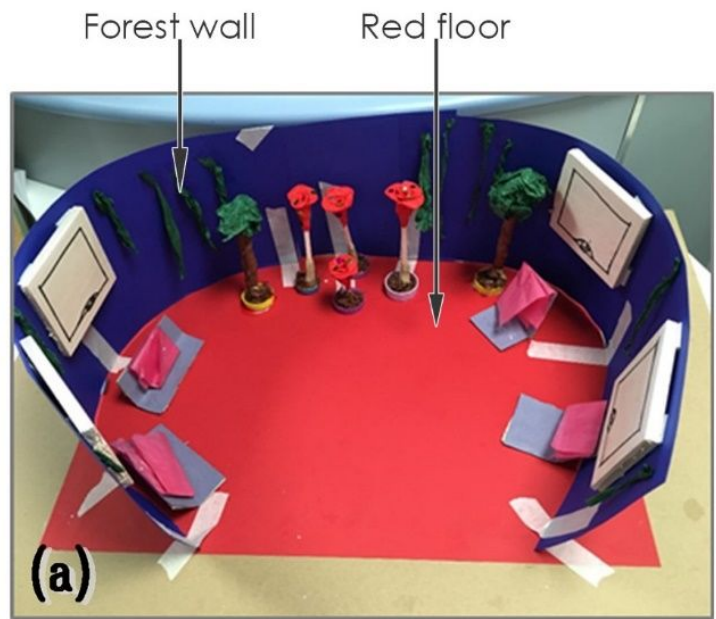

Hexagonal shape seats nested in the wall
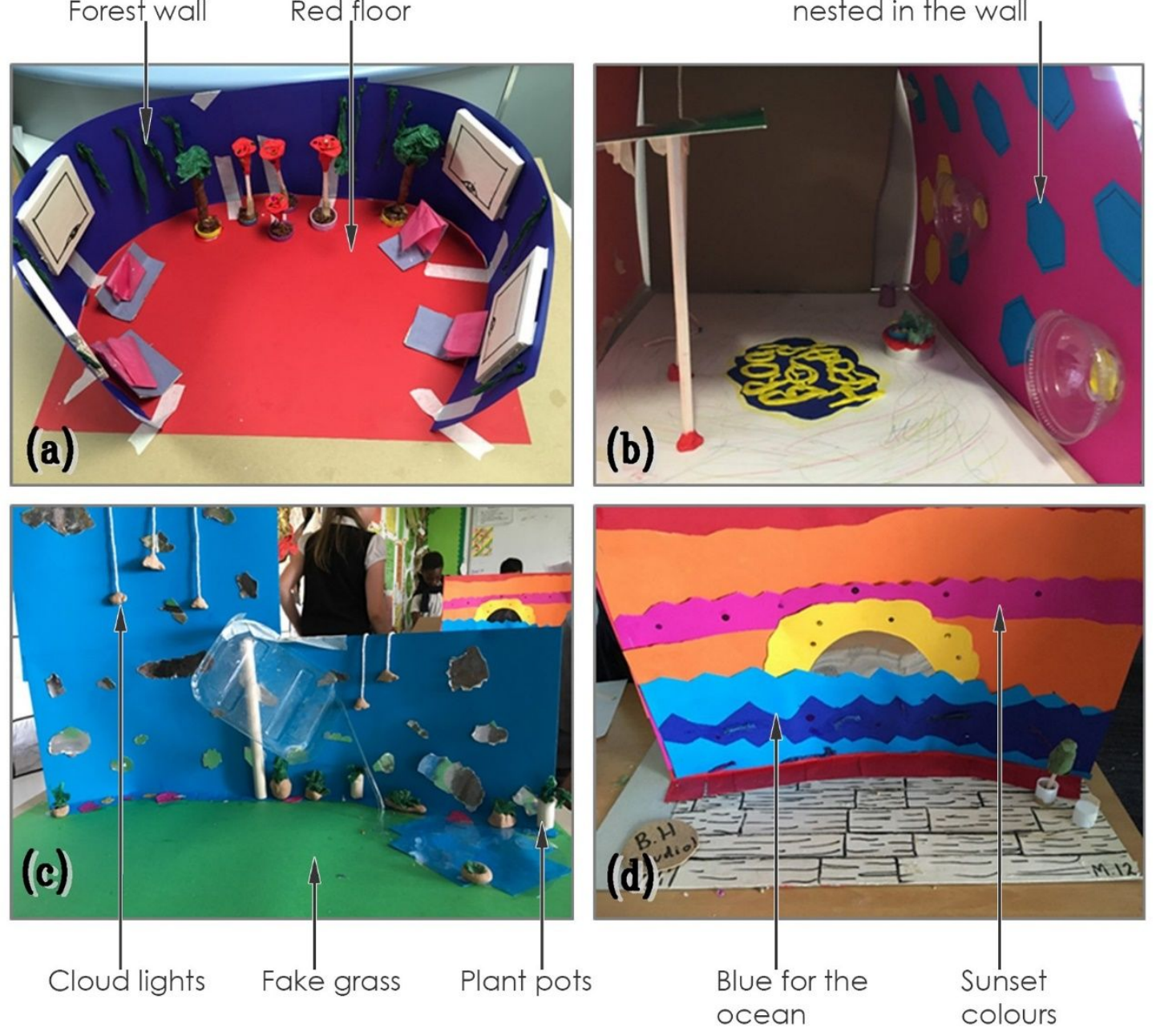

Figure 5 

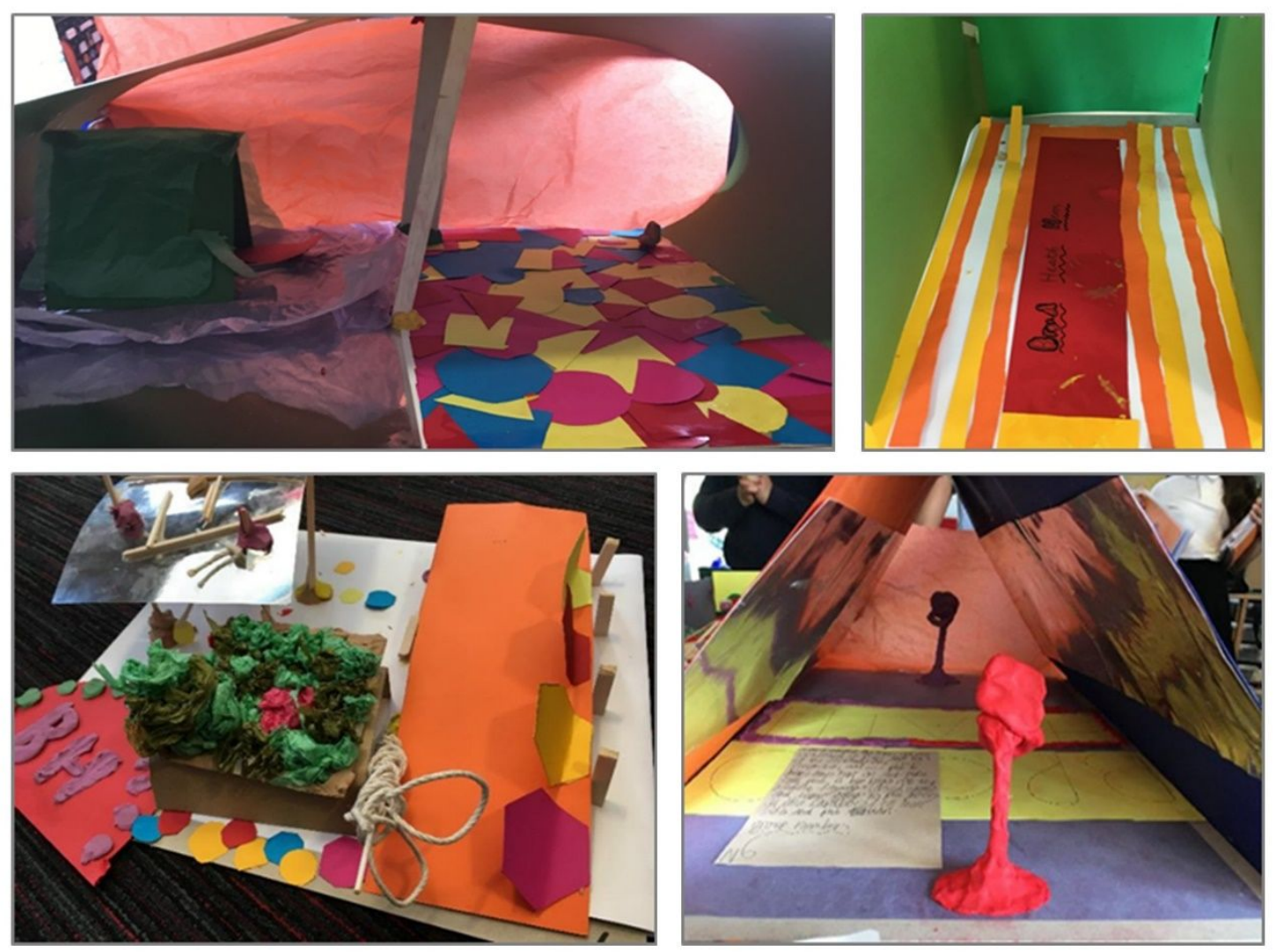

Figure 6

\section{List of Figures}

Figure 1. Children's drawings for suggested school garden

Figure 2. Model making process and final models of school garden

Figure 3. The existing Studio (a) and School Hall (b)

Figure 4. Children's drawings for re-designing the Studio

Figure 5. Children's models for re-designing the Studio

Figure 6. Children's models for re-designing the School Hall 


\section{Appendices}

\section{Appendix A: Questionnaire for Garden Design}

1. What are the activities that you will have in your garden?

2. How does your garden respond to different senses?

- Sound

- Touch

- Sight

- Smell

3. What features would you like in your future garden?

$\square$ children's play area

$\square$ grasses

$\checkmark$ garden

$\square$ evergreen

$\square$ shade

$\square$ landscape lighting

$\square$ flower garden

$\square 4$ season interest

$\square$ Sculpture

$\square$ Fence

$\square$ Gate

$\square$ Benches/seats

$\square$ Paths

$\square$ Other

4. What materials do you used in your garden?

5. Do you think this garden make you happier?

6. Do you think this garden help you feel relax? 


\section{Appendix B: Questionnaire for Re-design of School Hall and Studio}

1. What do you like most about your Hall/Studio?

2. What don't you like about your Hall/Studio?

3. What would you like to change and how?

\begin{tabular}{|l|l|}
\hline What would you like to change? & How? \\
\hline & \\
\hline & \\
\hline & \\
\hline & \\
\hline
\end{tabular}

4. Describe your 'dream Hall/Studio' that you would like to have in your school.

5. What colours will you choose?

6. How do you re-design the walls?

7. What artwork do you include in your design?

8. How do you re-design the floor?

9. How do you re-design the ceiling?

10. How do you design the lighting?

11. What type of furniture would you suggest? 